\title{
HIV seroprevalence in five key populations in Europe: a systematic literature review, 2009 to 2019
}

Annemarie Rinder Stengaard ${ }^{1}$, Lauren Combs ${ }^{1}$, Virginie Supervie ${ }^{2}$, Sara Croxford 3 , Sarika Desai ${ }^{3}$, Ann K Sullivan ${ }^{4}$, Stine Finne Jakobsen ${ }^{1}$, Quenia Santos ${ }^{1}$, Daniel Simões 5,6 , Jordi Casabona ${ }^{7,8}$, Jeffrey V Lazarus 9 , John B F de Wit ${ }^{10}$, Frank M Amort ${ }^{11}$, Anastasia Pharris ${ }^{12}$, Lina Nerlander ${ }^{12,{ }^{*}}$, Dorthe Raben ${ }^{1, *}$

1. Centre of Excellence for Health, Immunity and Infections (CHIP), Rigshospitalet, University of Copenhagen, Copenhagen, Denmark

2. Sorbonne Université, INSERM, Institut Pierre Louis d'Epidémiologie et de Santé Publique, Paris, France

3. Independent consultant, London, United Kingdom

4. Directorate of HIV and Sexual Health, Chelsea and Westminster Hospital NHS Foundation Trust, London, United Kingdom

5. EPIUnit-Instituto de Saúde Pública, Universidade do Porto, Rua das Taipas, $n^{\circ}{ }_{135}$, Porto, Portugal

6. Grupo de Ativistas em Tratamentos (GAT), Lisboa, Portugal

7. Centre d'Estudis Epidemiològics sobre les Infeccions de Transmissió Sexual i Sida de Catalunya (CEEISCAT), Barcelona, Spain

8. Centro de Investigación Biomédica en Red de Epidemiología y Salud Pública (CIBERESP), Barcelona, Spain

9. Barcelona Institute for Global Health (ISGlobal), Hospital Clínic, University of Barcelona, Barcelona, Spain

10. Department of Interdisciplinary Social Science, Utrecht University, Utrecht, Netherlands

11. FH JOANNEUM, University of Applied Sciences, Bad Gleichenberg, Austria

12. European Centre for Disease Prevention and Control (ECDC), Stockholm, Sweden

* These authors contributed equally to this article and share last authorship

Correspondence: Annemarie Rinder Stengaard (annemarie.rinder.stengaard@regionh.dk)

Citation style for this article:

Stengaard Annemarie Rinder, Combs Lauren, Supervie Virginie, Croxford Sara, Desai Sarika, Sullivan Ann K, Jakobsen Stine Finne, Santos Quenia, Simões Daniel, Casabona Jordi, Lazarus Jeffrey V, de Wit John B F, Amort Frank M, Pharris Anastasia, Nerlander Lina, Raben Dorthe. HIV seroprevalence in five key populations in Europe: a systematic literature review, 2009 to 2019. Euro Surveill. 2021;26(47):pii=2100044. https://doi.org/10.2807/1560-7917.ES.2021.26.47.2100044

Background: In Europe, HIV disproportionately affects men who have sex with men (MSM), people who inject drugs (PWID), prisoners, sex workers, and transgender people. Epidemiological data are primarily available from national HIV case surveillance systems that rarely capture information on sex work, gender identity or imprisonment. Surveillance of HIV prevalence in key populations often occurs as independent studies with no established mechanism for collating such information at the European level. Aim: We assessed HIV prevalence in MSM, PWID, prisoners, sex workers, and transgender people in the 30 European Union/ European Economic Area countries and the United Kingdom. Methods: We conducted a systematic literature review of peer-reviewed studies published during 2009-19, by searching PubMed, Embase and the Cochrane Library. Data are presented in forest plots by country, as simple prevalence or pooled across multiple studies. Results: Eighty-seven country- and population-specific studies were identified from 23 countries. The highest number of studies, and the largest variation in HIV prevalence, were identified for MSM, ranging from $2.4-29.0 \%$ (19 countries) and PWID, from $0.0-59.5 \%$ (13 countries). Prevalence ranged from $0.0-15.6 \%$ in prisoners (nine countries), $1.1-8.5 \%$ in sex workers (five countries) and was $10.9 \%$ in transgender people (one country). Individuals belonging to several key population groups had higher prevalence.
Conclusion: This review demonstrates that HIV prevalence is highly diverse across population groups and countries. People belonging to multiple key population groups are particularly vulnerable; however, more studies are needed, particularly for sex workers, transgender people and people with multiple risks.

\section{Introduction}

Men who have sex with men (MSM) and people who inject drugs (PWID) are - and have historically been disproportionately affected by HIV in Europe as well as globally, which has prompted many European countries to prioritise these groups for HIV prevention, testing, treatment and surveillance activities [1-6]. Thirty-nine percent of new HIV diagnoses reported in the European Union/European Economic Area (EU/EEA) in 2019 were attributed to sex between men. HIV transmission because of injecting drug use accounted for $4 \%$ of new diagnoses in the EU/EEA in 2019, but more than a quarter of new diagnoses in two countries and greater than $10 \%$ in another three [1]. Historically, PWID has accounted for a much higher proportion ( $>50 \%$ ) of AIDS cases in the mid-1990s in several of the large southern/western European countries [7]. However, other population groups such as prisoners, sex workers, and transgender people, as well as people belonging to several of these key population groups - while smaller in terms of population size and less studied - are also at higher risk for HIV and other sexually transmitted and 
FIGURE 1

PRISMA flow diagram with results of the systematic literature search and study selection

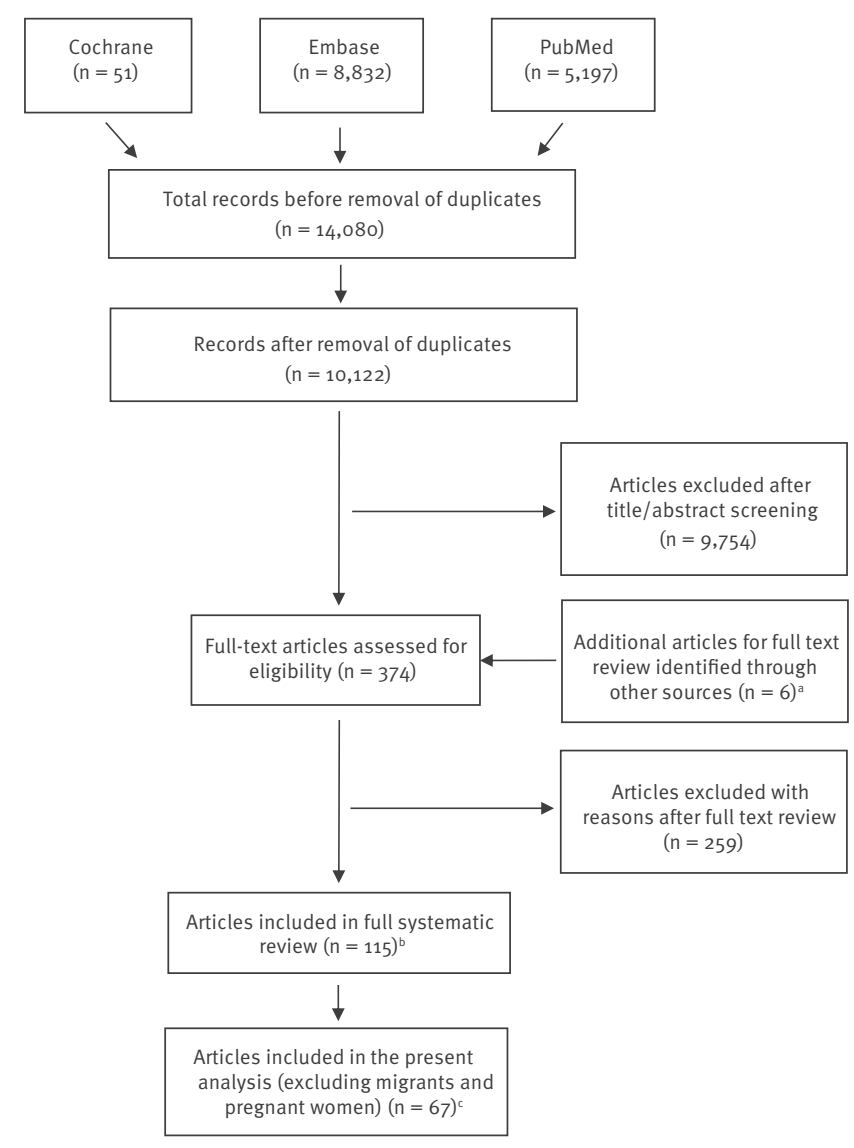

a Articles identified from screening titles and abstracts of secondary articles identified from reference lists of relevant systematic reviews.

${ }^{b}$ See [21].

' The 67 articles corresponded to 87 'studies', defined as a prevalence data point relating to a specific country or population group.

blood-borne infections because of a range of structural, legal, social, economic, behavioural and biological factors [8-12]. While country-specific estimates of the size of these key population groups vary across the EU/EEA countries and are scarce for some [13], available data suggest that MSM constitute between $0.03-5.6 \%$ of the adult (here, $15-64$ years) male population [14], PWID comprise $0.34 \%$ (range: $0.23-0.47$ ) of the adult (15-64 years) population [5], prisoners make up $0.13 \%$ (range: $0.003-0.39$ ) of the total population [15], sex workers constitute ca $0.3 \%$ (range: $0.05-0.7$ ) of the adult ( 15 years or older) female population [16] and transgender people are estimated to be between $0.39-2.7 \%$ of the total population [17]. Compared with these groups, the risk of HIV infection in the overall population is very low in the EU/EEA where HIV prevalence has been estimated at $0.2 \%$ overall [18], and ranges from less than $0.1 \%$ to $0.7 \%$ in countries with available data $[19,20]$.

Epidemiological data about the HIV epidemic in Europe are primarily available from national HIV case surveillance systems that collect basic demographic data on people newly diagnosed with HIV, including information on gender, age and probable route of HIV transmission [1]. Probable route of transmission captures data on exposure categories such as injecting drug use and sex between men. However, information on risk factors such as history of sex work or imprisonment and gender identity, e.g. transgender, is not routinely or uniformly collected for surveillance purposes in most countries. As such, notification data from these key population groups are lacking, as is information on people belonging to multiple key population groups, e.g. sex workers who inject drugs. Furthermore, data on new diagnoses do not provide a complete picture of the HIV epidemic since people with undiagnosed HIV are not captured and some countries do not adjust their data to take into account out-migration of people with HIV after they have been diagnosed and registered. Also, accurate population size estimates are often lacking, making it hard to generate prevalence figures from case surveillance data even if robust numerators were available by key population group.

These data limitations restrict our understanding of the epidemiology of HIV in key populations at higher risk of HIV in Europe. Bio-behavioural surveillance studies that assess risk factors for and seroprevalence of HIV in key population groups can help address these shortcomings and provide a broader understanding of the epidemiology of HIV in the EU/EEA. Currently in Europe, such bio-behavioural surveillance occurs in the form of one-off surveys of varying methodological robustness rather than repeated country-wide surveillance. Moreover, there is no established mechanism for collating this type of information at the European level. To assess the extent to which HIV affects European populations and to generate an additional source of information to better inform HIV prevention and control efforts in Europe, we conducted a systematic literature review of HIV seroprevalence among MSM, PWID, prisoners, sex workers, transgender people, migrants and pregnant women in the 30 EU/EEA countries and the UK. Here we report data for MSM, PWID, prisoners, sex workers and transgender people. Findings for migrants and pregnant women were also collated and are reported elsewhere [21].

\section{Methods}

This review was conducted in accordance with the Preferred Reporting Items for Systematic Reviews and Meta-Analyses (PRISMA) Statement [22].

Search strategy and selection criteria

Searches for peer-reviewed articles were conducted in PubMed, Embase and the Cochrane Library without any language restrictions on 17-19 June 2019. We used 
Included HIV prevalence studies for the European Union and European Economic Area and the United Kingdom, by country and population group, 2009-2019 ( $\mathrm{n}=87$ studies)

\begin{tabular}{|c|c|c|c|c|c|c|}
\hline \multirow[b]{2}{*}{ Country } & \multicolumn{6}{|c|}{ Number of studies by population group } \\
\hline & $\begin{array}{c}\text { MSM } \\
\left(\mathrm{n}=33^{\mathrm{a}}\right)\end{array}$ & $\begin{array}{c}\text { PWID } \\
\left(n=30^{b, c}\right)\end{array}$ & $\begin{array}{l}\text { Prisoners } \\
\left(\mathrm{n}=14^{\mathrm{b}}\right)\end{array}$ & $\begin{array}{c}\text { SW } \\
\left(n=9^{b}\right)\end{array}$ & $\begin{array}{c}\text { TG } \\
(n=1)\end{array}$ & $\begin{array}{c}\text { TOTAL } \\
(n=87)\end{array}$ \\
\hline Belgium & $2[24,29]$ & 0 & 0 & 0 & o & 2 \\
\hline Bulgaria & $1[24]$ & 0 & 0 & 0 & o & 1 \\
\hline Croatia & $2[25,26]$ & $5[25,39-42]$ & $1[68]$ & 0 & 0 & 8 \\
\hline Cyprus & $1[27]$ & 0 & 0 & 0 & o & 1 \\
\hline Czech Republic & $1[28]$ & 0 & 0 & 0 & 0 & 1 \\
\hline Estonia & 0 & $2[64,65]$ & $1[80]$ & 0 & 0 & 3 \\
\hline Finland & 0 & 0 & $1[69]$ & 0 & 0 & 1 \\
\hline France & $2[34,35]$ & $2[53,54]$ & $1[73]$ & 0 & 0 & 5 \\
\hline Germany & $1[24]$ & $2[43,66]$ & $1[70]$ & 0 & 0 & 4 \\
\hline Greece & 0 & $2[55,56]$ & 0 & 0 & 0 & 2 \\
\hline Hungary & 1 [30] & $1[44]$ & $2[71,72]$ & 0 & 0 & 4 \\
\hline Italy & $2[24,28]$ & $1[57]$ & $3[74-76]$ & $1[84]$ & $1[89]$ & 8 \\
\hline Lithuania & $1[24]$ & $1[44]$ & 0 & 0 & 0 & 2 \\
\hline Luxembourg & 0 & $1[45]$ & 0 & 0 & 0 & 1 \\
\hline Netherlands & $1[38]$ & 0 & 0 & $3[81-83]$ & 0 & 4 \\
\hline Poland & $1[24]$ & $1[58]$ & 0 & 0 & 0 & 2 \\
\hline Portugal & $1[24]$ & 0 & $1[77]$ & $2[87,88]$ & 0 & 4 \\
\hline Romania & $2[24,28]$ & 0 & 0 & 0 & 0 & 2 \\
\hline Slovakia & $2[24,28]$ & 0 & 0 & 0 & 0 & 2 \\
\hline Slovenia & $3[23,24,28]$ & 0 & 0 & 0 & 0 & 3 \\
\hline Spain & $4[24,28,36,37]$ & $5[59-63]$ & $3[67,78,79]$ & $2[36,85]$ & 0 & 14 \\
\hline Sweden & 1 [24] & $1[46]$ & 0 & 0 & 0 & 2 \\
\hline United Kingdom & $4[24,31-33]$ & $6[47-52]$ & 0 & $1[86]$ & 0 & 11 \\
\hline Countries with data $^{d}$ & 19 & 13 & 9 & 5 & 1 & 23 \\
\hline
\end{tabular}

EEA: European Economic Area; EU: European Union; MSM: men who have sex with men; PWID: people who inject drugs; SW: sex workers; TG: transgender people.

a One MSM study [23] was excluded from the plots because of a high risk of bias (summary bias score $=0$ ).

b This number includes studies of people belonging to multiple (overlapping) risk groups (five such studies for PWID [39,47,61,62,66], four for prisoners $[68,72,73,79]$, and seven for sex workers [81,82,84-88]).

' One PWID study [66] was excluded from the forest plots because the original dataset was reported in another study [43]. It was kept in the overview table here and the results description because it reported prevalence data for a different population sub-group (migrant PWID vs non-migrant PWID) which was not reported in the original study [43]. $d$ No peer-reviewed published studies were identified from eight of the 30 EU/EEA countries and the United Kingdom (Austria, Denmark, Iceland, Ireland, Latvia, Liechtenstein, Malta and Norway).

a combination of medical subject headings (MeSH) in PubMed and the Cochrane Library or Emtree terms and keywords in Embase. We included terms for HIV, prevalence, and the names of the relevant key population groups and then applied a geographical search filter to retrieve results for the EU/EEA countries. The detailed search strings are available in the supplement (Table S1a-c). All references retrieved were stored in an EndNote library and duplicates were removed with EndNote version X9 (Thomson Reuters, New York, United States (US)) and manually.

We included peer-reviewed articles of any study design published between 2009 and 2019 that reported HIV seroprevalence data in adults sampled in 2004 or later (Supplementary Table S2). For the purposes of this study, we considered adults as those aged $\geq 15$ years, given that behaviours associated with greater HIV acquisition risk, e.g. sexual contact or injecting drug use, become more prevalent from around that age. Inclusion was restricted to studies with the main purpose of measuring seroprevalence in the included population groups. Studies evaluating HIV testing interventions were excluded as these were often targeted at higher-risk groups within the key populations and frequently did not include people already living with diagnosed HIV when reporting positivity rates. Studies were included if descriptions of HIV testing methods and specimen sampling were available, i.e. studies presenting only self-reported HIV prevalence were excluded. Studies were also excluded if the sample size was fewer than 100 participants, except for studies of transgender people and studies of any population group from countries with a population of 1 


\section{FIGURE 2}

Simple or pooled HIV seroprevalence among men who have sex with men, by European Union/European Economic Area country and the United Kingdom, 2009-2019 ( $\mathrm{n}=32$ studies)

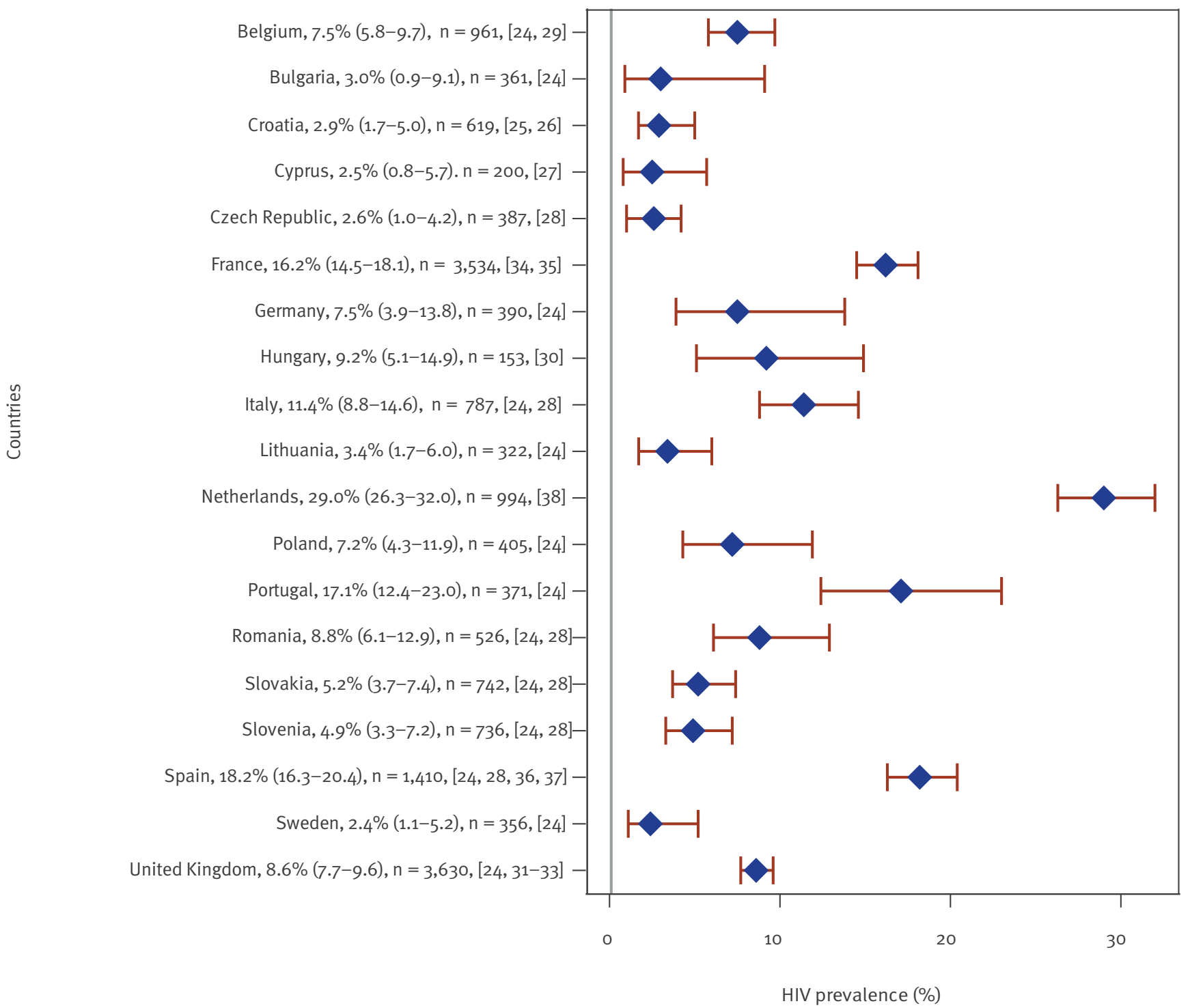

a Pooled prevalence estimates (combining data from multiple studies) were generated for nine countries with two or more studies available (Belgium, Croatia, France, Italy, Romania, Slovakia, Slovenia, Spain and the United Kingdom).

For each country examined, the mean HIV prevalence (blue diamonds), $95 \%$ confidence interval (red error bars), total number of participants (' $n$ ': the size of the study population, either from the individual study or the pooled studies combined) and respective references are given.

million or fewer inhabitants, for which sample sizes of 50 inhabitants or more were accepted. Grey literature and modelling studies were not included. Secondary references from all relevant systematic reviews identified from the search were checked to identify any additional relevant articles not appearing in the original search results.

\section{Screening and data extraction}

Title and abstract screening of all retrieved studies was carried out in pairs, independently of one another and based on the specified inclusion/exclusion criteria (all authors). If the two reviewers disagreed or inclusion could not be determined upon the first screening, then the full text of the article was reviewed. A third reviewer was consulted if consensus could not be reached. Full text articles were retrieved for all included abstracts.

Data extraction was performed simultaneously with the full text review of the articles (ARS, LC, DR, SF), AKS, VS, SC, SD). A data extraction protocol specifying all data items to be extracted was developed. Data extraction items included - but were not limited to the overall study characteristics, study population 
detail, sampling approach, recruitment setting, laboratory test and HIV prevalence. Each included article was also evaluated for its quality based on a framework that assessed the risk of bias related to the sampling method, sampling venue type/coverage and sample size; for studies of prisoners, risk of bias in terms of gender, age and drug injection was also assessed (Supplementary Table S3). Each criterion was scored with a value between 0 and 2 with higher scores indicating lower risk of bias. Overall (summary) quality scores were calculated for each study (Supplementary Table S4).

To ensure consistency in the data extraction, data were extracted in pairs independently for the first 20 articles and the results were compared. Any differences were discussed within the team and the data extraction protocol was refined accordingly. For the remaining articles, reviewers continued to work in pairs but independently performed full text reviews and provided decisions regarding inclusion/exclusion with reasons for exclusion of papers. One person then performed the main data extraction and the second person performed quality checks. Both reviewers also independently completed the bias assessments and the results were compared at the end of the process. Any discrepancies in the full text review decisions and/ or the bias scores were discussed within the pair and a third reviewer was consulted as required to provide input and reach consensus.

The unit for data extraction was 'study' and not 'article', i.e. if an article reported data from multiple distinct populations, e.g. prevalence data for MSM, PWID and sex workers, or for multiple countries, then each population or country-specific data point was treated as a 'study'. Inclusion criteria and risk of bias were evaluated at 'study' level to the extent permitted by available information. If the same dataset was reported in several articles, then the earliest article reporting on the full study population was retained.

\section{Data analysis}

Data were grouped by key population and presented in forest plots by country with simple or pooled (if two or more studies were identified) prevalence and 95\% confidence intervals (Cl), built using SAS studio (SAS Institute, Cary, North Carolina, US). If the $\mathrm{CI}$ was missing from the extracted data, study-specific $95 \% \mathrm{Cl}$ were calculated using Fisher's exact test. Studies of lower quality (with summary bias scores of o) were removed from the forest plots, provided that other studies were available for that given country or population group. If prevalence was reported by city, gender or other population sub-group alone, then overall prevalence was calculated and the study included in the forest plots. If a study reported data for multiple time points, then the most recent data point was used. All prevalence numbers were rounded to one decimal point in text, figures and tables.

\section{Results}

The results of our full original literature search covering MSM, PWID, prisoners, sex workers, transgender people, migrants and pregnant women [21] and the selection of studies are outlined in Figure 1. A total of 67 articles reporting HIV seroprevalence in MSM, PWID, prisoners, sex workers and transgender people from $23 \mathrm{EU} / \mathrm{EEA}$ countries, including five in languages other than English, were included in this analysis, which corresponded to 87 'studies'. The largest number of studies, i.e. data points, were identified for MSM $(n=33)$ and PWID $(n=30)$, followed by prisoners $(n=14)$, sex workers $(n=9)$ and transgender people $(n=1)$. Fifteen of the studies included data for people belonging to multiple (overlapping) risk groups ( $n=5$ for PWID, $n=7$ for sex workers and $n=4$ for prisoners (Table). The highest number of studies were conducted in Spain $(n=14)$, the United Kingdom (UK) $(n=11)$, Italy $(n=8)$ and Croatia $(n=8)$. No peer-reviewed published studies that met our inclusion criteria were identified from the following eight EU/EEA countries: Austria, Denmark, Iceland, Ireland, Latvia, Liechtenstein, Malta and Norway.

\section{Men who have sex with men}

Of the 33 studies of HIV prevalence among MSM from 19 countries, 32 were included; one [23] study with a summary bias score of o, i.e. high estimated risk of bias, was excluded (see also Supplementary Table S4). Of the 32 studies included, nearly all studies recruited participants through community-based sampling approaches (time-location, respondent-driven or convenience sampling). Simple or pooled HIV prevalence was $<5 \%$ in seven countries (Bulgaria [24], Croatia [25,26], Cyprus [27], the Czech Republic [28], Lithuania [24], Slovenia $[24,28]$ and Sweden $[24]), \geq 5 \%$ to $<10 \%$ in seven countries (Belgium [24,29], Germany [24], Hungary [30], Poland [24], Romania [24,28], Slovakia [24,28] and the UK $[24,31-33])$ and highest, $\geq 10 \%$ to $<20 \%$, in four western/southern European countries (France [34,35], Italy $[24,28]$, Portugal $[24]$ and Spain $[24,28,36,37]$ ) (Figure 2). In one study from the Netherlands [38], conducted in a single low-threshold public sexually transmitted infection (STI) clinic in Amsterdam, prevalence was $29.0 \%$. The majority $(n=30)$ of the MSM studies were conducted in urban areas, either the capital or another major city, while the remaining three $[18,20,28]$ had national or near-national coverage.

\section{People who inject drugs}

Of the 30 studies of HIV prevalence among PWID, 29 were included from 13 countries, half of the studies were set in the UK $(n=6)$, Spain $(n=5)$ and Croatia $(n=5)$ (Figure 3). For 22 studies, participants were recruited through harm reduction or drug dependence treatment sites while the remaining studies were primarily based on respondent-driven sampling (RDS). HIV prevalence (simple or pooled) varied greatly and was lowest in the central and northern parts of Europe: $\langle 5 \%$ in six countries (Croatia [25,39-42], Germany [43], Hungary [44], Luxembourg [45], Sweden [46] and the UK [47-52]), $\geq 5 \%$ 


\section{FIGURE 3}

Simple or pooled HIV seroprevalence among people who inject drugs, by European Union/European Economic Area country and the United Kingdom, 2009-2019 ( $\mathrm{n}=29$ studies)

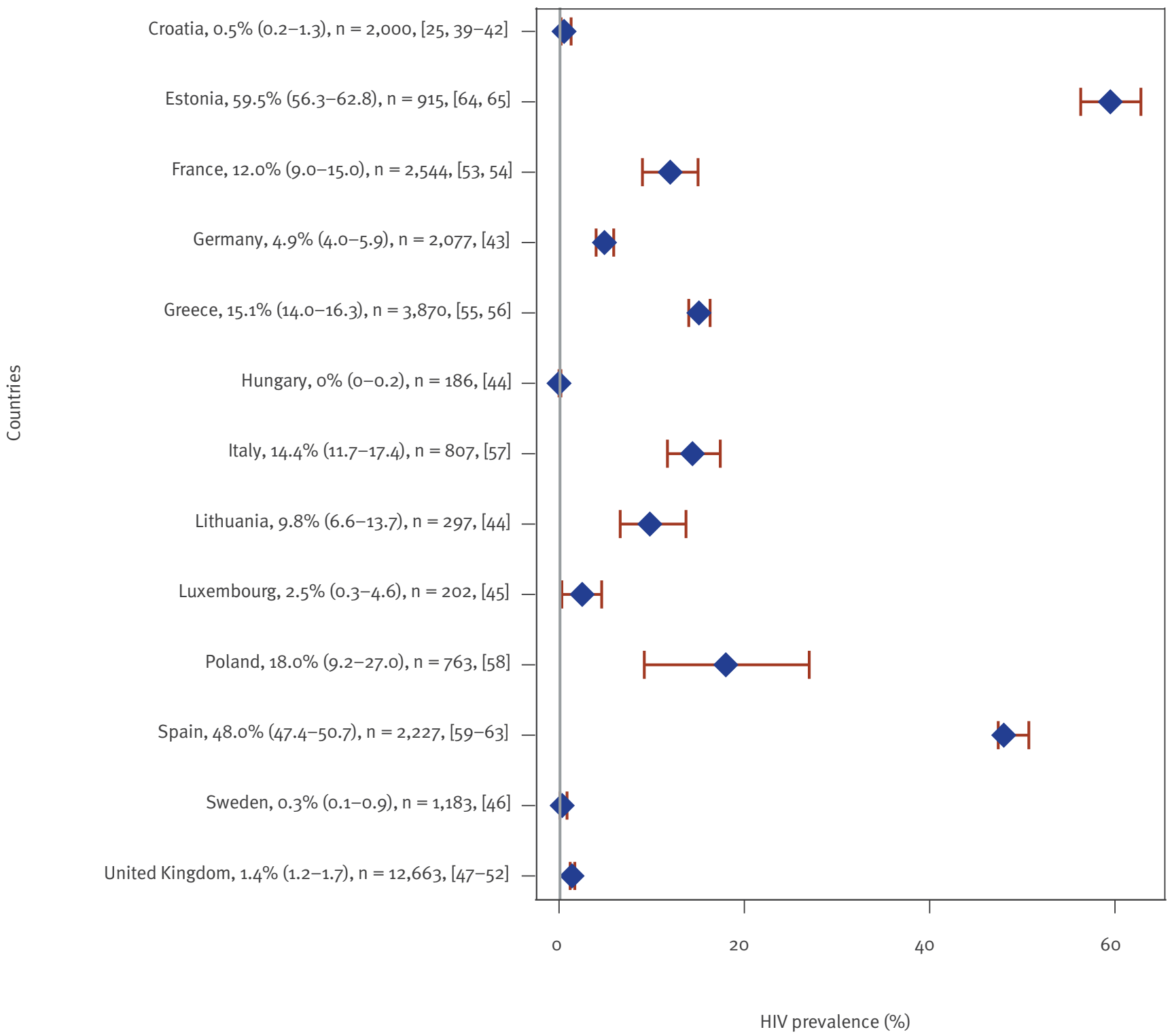

\footnotetext{
a Pooled prevalence estimates (combining data from multiple studies) were generated for six countries with 2 or more studies available (Croatia, Estonia, France, Greece, Spain and the United Kingdom).
}

For each country examined, the mean HIV prevalence (blue diamonds), $95 \%$ confidence interval (red error bars), total number of participants (' $n$ ': size of the study population, either from the individual study or the pooled studies combined) and respective references are given.

to $<10 \%$ in Lithuania [44], $\geq 10 \%$ to $<20 \%$ in four countries (France [53,54], Greece [55,56], Italy [57] and Poland [58]), and $48.0 \%$ in Spain [59-63] and 59.5\% in Estonia [64,65] (Figure 3). One study [66] was excluded because the original dataset was reported in another study [43] but provided prevalence data for a different population sub-group.

Among PWID with overlapping risk factors (Supplementary Table S4), prevalence was highest among female PWID who were also sex workers (53.3\% vs $33.3 \%$ in PWID who were not performing sex work, p<0.001, in a study from Spain [62]). In a UK-based study, men who have sex with men and inject drugs had an HIV prevalence of $3.2 \%$, which was four times higher than that found among men who have sex with women and inject drugs (o.8\%; odds ratio $=4.08$; 95\% Cl: 1.9-8.5) [47]. Migrant PWID from the postSoviet states tended to have higher prevalence than non-migrant PWID (5.8\% vs $4.6 \%$ ) in a study from eight cities in Germany [66]. Conversely, in a study from Catalonia, Spain, where background HIV prevalence among PWID is one of the highest reported, migrant PWID had significantly lower prevalence than 
non-migrant PWID (22.4\% vs $43.0 \%$; p<0.001), where migrants were from Europe - both western and eastern Europe - and Africa [61].

\section{Prisoners}

Fourteen studies of HIV prevalence among prisoners were identified from nine countries, with half conducted in three countries: Italy $(n=3)$, Spain $(n=3)$ and Hungary $(n=2)$. One study [67] could not be included in the forest plots because of missing $95 \%$ $\mathrm{Cl}$ and missing information required for $\mathrm{Cl}$ calculation. Two thirds of the studies on prisoners were conducted in the western part of Europe. Simple or pooled HIV prevalence was $<2 \%$ in four countries (Croatia [68], Finland [69], Germany [70] and Hungary [71,72]), $\geq 2 \%$ to $<5 \%$ in France [73] and Italy [74-76] and $\geq 5 \%$ to $<10 \%$ in Portugal [77] and Spain [67,78,79], and highest at $15.6 \%$ in Estonia [80] (Figure 4).

Among prisoners belonging to multiple risk groups (Supplementary Table S4. Overview of included HIV seroprevalence studies with key results parameters, by population group and EU/EEA country), prevalence was higher among prisoners who inject drugs compared with those who did not: $39.0 \%$ compared with $15.7 \%$ in a study from Spain [79], and $0.5 \%$ compared with $0.15 \%$ in the general prison population in a study from Croatia [68]. Two studies had information about country of origin, but results were inconsistent. One French study found that French-born prisoners had lower prevalence $(1.1 \%)$ than prisoners from sub-Saharan Africa (15.4\%) but not significantly lower prevalence levels than prisoners from North Africa (3.2\%) and the Americas (3.5\%) [73]. A study from Spain found that HIV prevalence was higher among Spanish-born prisoners compared with those born abroad [79].

\section{Sex workers}

Nine studies of HIV prevalence among sex workers were included from five countries, the majority from the Netherlands $(n=3)$, Portugal $(n=2)$ and Spain $(n=2)$. Six were based on community-based sampling, of which three were clinic-based and one used a combination of outreach and clinic-based recruitment. Prevalence was $<5 \%$ in four countries (the Netherlands [81-83], Italy [84], Spain [36,85] and the UK [86]) and slightly higher at $8.5 \%$ in the pooled studies from Portugal [87,88] (Figure 5).

Among sex workers with multiple risk factors (Supplementary Table S4), prevalence was highest among transgender sex workers (18.8\% in the Netherlands [81] and $22.2 \%$ in Portugal [87]) and sex workers who inject drugs $13.6 \%$ in the Netherlands [81]). In a study of male sex workers, also from the Netherlands, prevalence was $0.1 \%$ among heterosexual male sex workers but $3.4 \%$ among gay/bisexual male sex workers $(p<0.001)$ [82]. Migrant sex workers (from eastern Europe, Africa and Latin America) had significantly lower prevalence (0.3\%) than non-migrant sex workers (14.7\%) in a Spanish study [85]. A study from the UK found that migrant (from eastern Europe) and non-migrant sex workers had similar prevalence levels (1.2\% and $0.9 \%$, respectively) [86]. In a Portuguese study [88], documented migrant sex workers tended to have lower prevalence $(2.3 \%)$ than both non-migrant sex workers (8.0\%) and undocumented migrant sex workers (13.6\%). The migrant sex workers (documented and undocumented) originated from Latin America (63\%), Africa (26\%) and Europe (11\%).

\section{Transgender people}

Only one study of HIV prevalence among transgender people was identified. This clinic-based study set in Italy reported HIV seroprevalence of $12.1 \%$ in 173 people transitioning from male-to-female gender [89]. In addition, as described above, two other studies reported high prevalence among transgender sex workers at $18.8 \%$ in the Netherlands $[81,87]$ and $22.2 \%$ in Portugal [87].

\section{Discussion}

This review of HIV seroprevalence in the EU/EEA and the UK shows that prevalence is highly diverse across population groups and countries. In terms of populations, our findings suggest that HIV prevalence was highest among MSM and PWID but varied within all groups. However, we also identified more studies for MSM and PWID, exposing a knowledge gap regarding HIV prevalence in the other population groups for a large number of countries, particularly transgender people but also sex workers, for which evidence was confined to two countries in the northern and two in the south-western parts of Europe. Furthermore, we found that individuals with multiple risk factors had higher prevalence than those belonging to one key population group only.

For MSM and PWID, prevalence was highest in the western and southern parts of Europe where the HIV epidemics are older, largely reflecting historical transmission [7], but it was also high in some of the more eastern EU/EEA countries. For MSM, however, incidence appears to have been declining in several western EU/EEA countries, as reflected by a decrease in new HIV diagnoses among MSM in Austria, Belgium, Finland, France, Germany, Greece, Italy, the Netherlands, Portugal and the UK [1]; this trend is likely a result of a combination of prevention interventions, focused and more frequent HIV testing, rapid linkage to care and initiation of antiretroviral therapy (ART), and could potentially lead to reductions in prevalence in the future. Conversely, in the central and eastern EU/ EEA, new HIV diagnoses among MSM have increased in recent years in Bulgaria, Cyprus, Poland, Romania and Slovakia, calling for a need to ensure that comprehensive MSM-friendly HIV services are available; this trend suggests that prevalence may also continue to increase in this part of Europe. This review identified relatively few studies of MSM with multiple risks, e.g. foreign-born, PWID or MSM sex workers; however, evidence from France, Belgium and Spain has demonstrated that undiagnosed HIV prevalence appears to be 


\section{FIGURE 4}

Simple or pooled HIV seroprevalence ${ }^{\mathrm{a}}$ among prisoners, by European Union/European Economic Area country and the United Kingdom, 2009-2019 ( $\mathrm{n}=14$ studies)

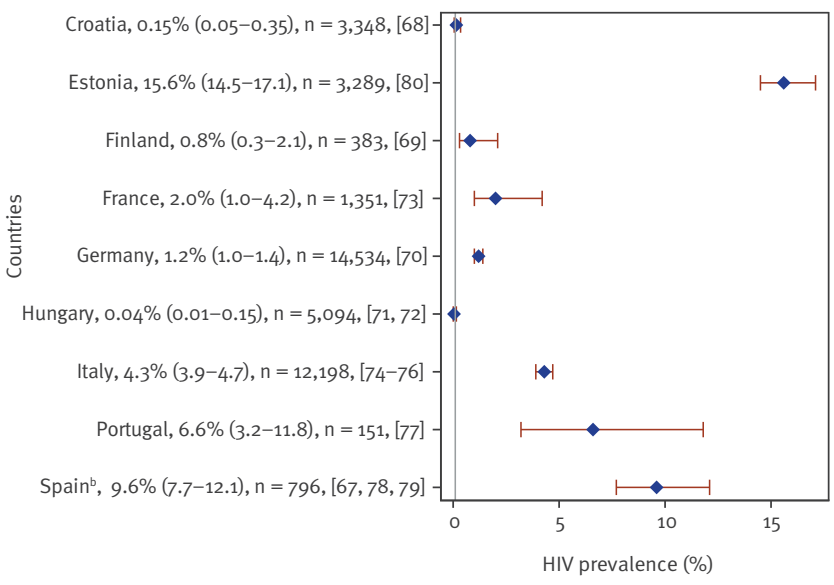

a Pooled prevalence estimates (combining data from multiple studies) were generated for three countries with two or more studies available (Hungary, Italy and Spain).

${ }^{b}$ One additional study from Spain [67] reported prevalence of $7.0 \%$ but was not included in the pooled prevalence because of missing information about $n$.

For each country examined, the mean HIV prevalence (blue diamonds), $95 \%$ confidence interval (red error bars), total number of participants ('n': size of the study population, either from the individual study or the pooled studies combined) and respective references are given.

higher in foreign-born MSM compared with non-foreign born MSM [90-92]. For PWID, prevalence varied even more across the EU/EEA, possibly reflecting timing differences in implementation of effective harm reduction programmes, where countries that implemented comprehensive harm reduction interventions early on in the epidemic currently observe lower prevalence levels [50]. Localised outbreaks, such as those occurring in Greece and Romania in 2011-13 [55,93], also contribute to the observed differences in HIV prevalence among PWID and illustrate the importance of maintaining adequate coverage of harm reduction services even in low prevalence settings [94]. Limited, but important, findings related to sex differences indicate that prevalence was higher among female PWID compared with male PWID, suggesting that female PWID may face particular vulnerabilities, including risks of sexual violence, engagement in sex work and dependence on male injecting partners for access to drugs and injecting equipment, as reported elsewhere [95].

Prevalence of HIV and related co-infections is generally higher among prisoners than in the general population in many countries. This is related to high levels of injecting drug use among prisoners, ranging from $2.5 \%$ to $37.8 \%$ in 15 selected European countries, which represents seven of the nine countries included in this review [96], as well as limited access to harm reduction in some prison settings. HIV prevalence among prisoners was relatively low ( $<2 \%$ ) in about half of identified studies and highest among prisoners who inject drugs, which largely reflects differences in HIV prevalence overall and among PWID in different countries and is consistent with findings reported in a recent global review [10]. Criminalisation of drug use and a related overrepresentation of PWID among prisoners in some countries may also contribute to the observed variation in prevalence.

Prevalence was also relatively low among sex workers who did not belong to other key population groups, ranging from $1.1 \%$ to $8.5 \%$ overall, and much higher in sex workers who inject drugs and transgender sex workers, ranging from $13.6 \%$ to $22.2 \%$. However, data were scarce and covered only five of the $30 \mathrm{EU} / \mathrm{EEA}$ countries and the UK. Social, political and cultural contexts such as poverty, risk of violence, criminalisation, discrimination and stigma contribute to increased vulnerabilities among sex workers [11]. Additional structural factors, such as the organisation of sex work and the legal and regulatory policies regarding sex work, may limit sex workers' ability to negotiate safer sex and access HIV prevention services, and thus further increase the risk of HIV transmission [9].

Data regarding migrant and non-migrant PWID, prisoners and sex workers suggested that that prevalence was higher among foreign-born than non-foreign-born migrants in some countries, and lower in others. This may be explained by differences in levels of injecting drug use in the non-migrant sex workers and prison populations in some countries, a key risk factor for HIV in both populations $[10,11]$. This may also reflect different background HIV prevalence levels among nonmigrant PWID, e.g. high in Spain and low in Germany, and among non-migrant sex workers as well as background prevalence in the migrant's countries of origin [21]. Of note, when interpreting our results, it should be mentioned that HIV prevalence in a given population does not necessarily reflect the accumulated transmission that has occurred in the country where the prevalence study was conducted since some people living with HIV may have acquired HIV before migrating into that country [97].

We found extremely limited published data on HIV prevalence among transgender people. Although prevalence was high (12.1\%) in the single study identified in our review, previous studies from Europe and the United States [12] have reported even higher prevalence levels, particularly among transgender women, with reported pooled prevalence of $19.1 \%$ worldwide, $21.6 \%$ in five high-income countries, and consistently high infection rates across regions and independent of income level and social, cultural and legal contexts. These findings indicate an urgent need for prevention, testing and care services, as well as additional studies, in this highly vulnerable population group. 


\section{FIGURE 5}

Simple or pooled HIV seroprevalence ${ }^{\mathrm{a}}$ among sex workers, by European Union/European Economic Area country and the United Kingdom, 2009-2019 ( $\mathrm{n}=9$ studies)

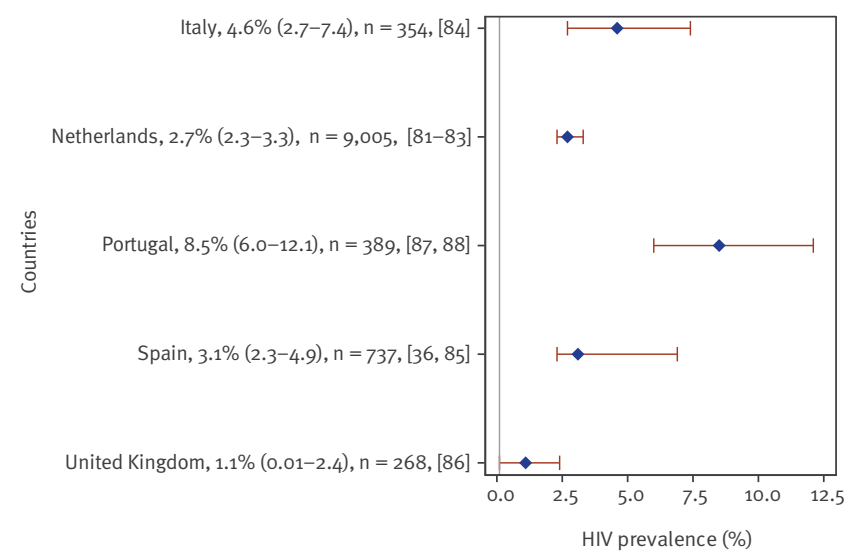

a Pooled prevalence estimates (combining data from multiple studies) were generated for three countries with 2 or more studies available (the Netherlands, Portugal and Spain).

For each country examined, the mean HIV prevalence (blue diamonds), 95\% confidence interval (red error bars), total number of participants ('n': size of the study population, either from the individual study or the pooled studies combined) and respective references are given.

Overall, our findings demonstrate that people with overlapping risks are particularly vulnerable - and especially in need of people-centred HIV services. However, more studies are warranted to better understand the sub-group dynamics in the intersections of these high-risk population groups and to inform the design of tailored interventions. There is a continuing need to ensure that key populations at higher risk of HIV have equitable access to HIV services in an environment free of stigma and discrimination, which aim to reduce the risk of infection and onward transmission for these population groups. Evidence-based combination prevention programmes seek to achieve maximum impact on HIV incidence by implementing complementary behavioural, biomedical and structural strategies in the context of a well-researched and understood local epidemiology [98]. Some key elements of combination HIV prevention, include condom provision, pre- and post-exposure prophylaxis (PrEP and PEP), expansion of HIV testing, prompt initiation of antiretroviral treatment (ART) after HIV diagnosis as well as provisions of clean injecting equipment and opioid substitution therapy for PWID [99]. Prison settings present not only challenges but also opportunities for prevention and treatment of HIV and related co-infections. Decriminalisation of drug use and sex work can help the implementation of tailored services and reduce the number of sex workers working in unsafe environments, reducing the risk of HIV transmission both for PWID, sex workers and their partners. Structural measures to reduce social and healthcare related discrimination, marginalisation and violence, alongside other comprehensive social services, can help increase use of HIV and other healthcare services among MSM and transgender people $[12,89,100]$.

Our review has several limitations. Firstly, we only included seroprevalence studies from the published peer-reviewed literature. Hence, unpublished prevalence data or grey literature such as national HIV/STI surveillance reports reporting on prevalence or reports of studies conducted by non-government organisations or other research entities are missing from this review, leaving a gap in the amount of data captured in this analysis. Secondly, sampling methods, recruitment settings and study populations varied greatly across the different studies, impeding the comparability of the data and the methodological robustness of some. Thirdly, a large proportion of studies recruited participants through convenience sampling in a single city or study site and cannot be considered representative of the underlying population at the national level in a given country. Our review includes data sampled in 2004 or later, hence covering a relatively long time period, which may impede direct comparability between older and more recent studies. In terms of the criteria for assessing the risk of bias, the relatively narrow categories for scoring the study sample sizes (100-199; 200+) mean that studies including just over 200 participants received the same risk of bias score as studies covering much larger study samples. Finally, this review covered only studies reporting on measured seroprevalence; many countries now use modelling approaches, which draw on a wide variety of existing surveillance data and serve as an additional robust source of information to assess undiagnosed and total HIV prevalence, overall and in key populations at higher risk.

\section{Conclusions}

This review synthesises previously uncollated evidence on the seroprevalence of HIV across five key population groups in the EU/EEA - MSM, PWID, prisoners, sex workers and transgender people - and also examined combined risk factors and prevalence in people belonging to multiple key population groups. Our results complement other available data sources on the epidemiology of HIV in Europe, particularly HIV case surveillance data published at the European and national level, by providing additional information about HIV prevalence in key populations that are not covered as part of most routine case surveillance data (notably concerning prisoners, sex workers, and transgender people). As such, our findings provide important information for groups who are planning and designing national and local HIV prevention, testing, care and support interventions and serve as a reference for countries with limited or no data. However, the availability of published data varies substantially by country and population group, reflecting both the availability of existing information and the extent to which the data are published in the peer-reviewed literature. In sum, there are limited data and a need to prioritise conducting and publishing HIV seroprevalence studies - particularly among 
transgender people, but also among male sex workers, female PWID, MSM living outside of capital cities and people with overlapping risks - preferably conducted in a harmonised manner as part of wider national surveillance programmes that include bio-behavioural, modelling and other epidemiologic studies.

\section{Acknowledgements}

The authors would like to thank the ECDC librarians for providing input to the search strings; ECDC colleagues and Maja Ilic from the Croatian Institute of Public Health for helping to screen abstracts and extract data from articles published in languages other than English, Spanish, French, German, Dutch, Portuguese, Danish and Russian; and the researchers who shared the full texts of their articles when otherwise not accessible: Cinta Folch (Centre d'Estudis Epidemiològics sobre les Infeccions de Transmissió Sexual i Sida de Catalunya (CEEISCAT), Barcelona, Spain), Ana Kolovrat (Institute of Public Health, Brod-Posavina County, Croatia), Ambrogio Pietro Londero (Azienda Ospedaliero-Universita Santa Maria della Misericordia, Udine, Italy) and Bernd Schulte (Zentrum für Interdisziplinäre Suchtforschung der Universität Hamburg, Germany).

Funding statement: This work was funded by the European Centre for Disease Prevention and Control (ECDC) through a service contract (ECD.9585) and the overall scope of the work was pre-defined.

\section{Conflict of interest}

VS has served on advisory boards for ViiV Healthcare (2016) and Gilead (2018) and reports lecture fees from Gilead $(2017,2019,2020)$, Janssen $(2018,2020)$ and ViiV (2019), Abbvie (2018), outside the submitted work. DS is the recipient of PhD Grant PD/BD/128008/2016 from Fundação para a Ciência e Tecnologia (FCT). JVL has received speaker fees and grants from AbbVie, Gilead Sciences and MSD, outside the submitted work.

\section{Authors' contributions}

All authors contributed important intellectual content to this paper. ARS, LN, AP and DR coordinated the systematic review process; ARS, LN, LC, VS, SC, SD, AKS and DR developed the protocols and prepared the search terms; VS, SC and SD conducted the database searches. ARS, LC, VS, SC, SD, AKS, SFJ, DS, JC, JVL, JW, FA, AP, DR and LN contributed equally to the title and abstract screening; ARS, LC, DR, SFJ, AKS, VS, SC and SD performed the data extraction and quality assessment. ARS, LC and QS compiled the results and performed the data analysis based on input from all authors. ARS drafted the manuscript; all authors (ARS, LC, VS, SC, SD, AKS, SFJ, QS, DS, JC, JVL, JW, FA, AP, DR and LN) critically revised the text and approved the final draft.

\section{References}

1. European Centre for Disease Prevention and Control (ECDC)/World Health Organization (WHO) Regional Office for Europe. HIV/AIDS surveillance in Europe 2020 - 2019 data. Copenhagen: WHO/Europe; 2020. Available from: https://www.euro.who.int/en/publications/abstracts/ hivaids-surveillance-in-europe-2020-2019-data

2. European Centre for Disease Prevention and Control (ECDC). HIV and men who have sex with men. Monitoring implementation of the Dublin Declaration on partnership to fight HIV/AIDS in Europe and Central Asia: 2018 progress report. Stockholm: ECDC; 2020. Available from: https://www.
ecdc.europa.eu/sites/default/files/documents/HIV-men-whohave-sex-with-men-Dublin-declaration.pdf

3. European Centre for Disease Prevention and Control (ECDC). HIV and people who inject drugs. Monitoring implementation of the Dublin Declaration on partnership to fight HIV/AIDS in Europe and Central Asia: 2018 progress report. Stockholm: ECDC; 2019. Available from: https://www.ecdc.europa.eu/ sites/default/files/documents/HIV-people-who-inject-drugsDublin-Declaration.pdf

4. Beyrer C, Baral SD, Walker D, Wirtz AL, Johns B, Sifakis F. The expanding epidemics of HIV type 1 among men who have sex with men in low- and middle-income countries: diversity and consistency. Epidemiol Rev. 2010;32(1):137-51. https://doi. org/10.1093/epirev/mxq011 PMID: 20573756

5. Degenhardt L, Peacock A, Colledge S, Leung J, Grebely J, Vickerman P, et al. Global prevalence of injecting drug use and sociodemographic characteristics and prevalence of HIV, HBV, and HCV in people who inject drugs: a multistage systematic review. Lancet Glob Health. 2017;5(12):e1192-207. https://doi. org/10.1016/S2214-109X(17)30375-3 PMID: 29074409

6. Mathers BM, Degenhardt L, Ali H, Wiessing L, Hickman M, Mattick RP, et al. HIV prevention, treatment, and care services for people who inject drugs: a systematic review of global, regional, and national coverage. Lancet. 2010;375(9719):1014 28. https://doi.org/10.1016/S0140-6736(10)60232-2 PMID: 20189638

7. EuroHIV. HIV/AIDS Surveillance in Europe. End-year report 2006. No. 75. Saint-Maurice: Institut de veille sanitaire; 2007. Available from: https://www.pnvihsida.dgs.pt/estudos-eestatisticas111111/relatorios1/internacionais-europeus1/oms1/ eurohiv-hivaids-surveillance-in-europe-no-751.aspx

8. Baral S, Beyrer C, Muessig K, Poteat T, Wirtz AL, Decker MR, et al. Burden of HIV among female sex workers in low-income and middle-income countries: a systematic review and metaanalysis. Lancet Infect Dis. 2012;12(7):538-49. https://doi. org/10.1016/S1473-3099(12)70066-X PMID: 22424777

9. Baral SD, Friedman MR, Geibel S, Rebe K, Bozhinov B, Diouf $D$, et al. Male sex workers: practices, contexts, and vulnerabilities for HIV acquisition and transmission. Lancet. 2015;385(9964):260-73. https://doi.org/10.1016/S01406736(14)60801-1 PMID: 25059939

10. Dolan K, Wirtz AL, Moazen B, Ndeffo-Mbah M, Galvani A, Kinner SA, et al. Global burden of HIV, viral hepatitis, and tuberculosis in prisoners and detainees. Lancet. 2016;388(10049):1089-102. https://doi.org/10.1016/S01406736(16)30466-4 PMID: 27427453

11. Platt L, Jolley E, Rhodes T, Hope V, Latypov A, Reynolds L, et al. Factors mediating HIV risk among female sex workers in Europe: a systematic review and ecological analysis. BMJ Open. 2013;3(7):e002836. https://doi.org/10.1136/ bmjopen-2013-002836 PMID: 23883879

12. Baral SD, Poteat T, Strömdahl S, Wirtz AL, Guadamuz TE, Beyrer C. Worldwide burden of HIV in transgender women: a systematic review and meta-analysis. Lancet Infect Dis. 2013;13(3):214-22. https://doi.org/10.1016/S14733099(12)70315-8 PMID: 23260128

13. UNAIDS. Key population atlas. Geneva: UNAIDS. [Accessed: 27 May 2021]. Available from: https://kpatlas.unaids.org/ dashboard

14. Marcus U, Hickson F, Weatherburn P, Schmidt AJ, EMIS Network. Estimating the size of the MSM populations for 38 European countries by calculating the survey-surveillance discrepancies (SSD) between self-reported new HIV diagnoses from the European MSM internet survey (EMIS) and surveillance-reported HIV diagnoses among MSM in 2009. BMC Public Health. 2013;13(1):919. https://doi.org/10.1186/14712458-13-919 PMID: 24088198

15. Aebi MF, Tiago MM. Prisons and Prisoners in Europe 2019: Key Findings of the SPACE I report. Strasbourg: Council of Europe; 2020. Available from: https://wp.unil.ch/space/files/2020/04/ Key-Findings-2019_200406.pdf

16. Adair P, Nezhyvenko 0 . Assessing how large is the market for prostitution in the European Union. Éthique et économique / Ethics and economics. 2017;14(2):116-36. Available from: https://hal.archives-ouvertes.fr/hal-01672872

17. Nolan IT, Kuhner CJ, Dy GW. Demographic and temporal trends in transgender identities and gender confirming surgery. Transl Androl Urol. 2019;8(3):184-90. https://doi.org/10.21037/ tau.2019.04.09 PMID: 31380225

18. Pharris A, Quinten C, Noori T, Amato-Gauci AJ, van Sighem A, ECDC HIV/AIDS Surveillance and Dublin Declaration Monitoring Networks. Estimating HIV incidence and number of undiagnosed individuals living with HIV in the European Union/European Economic Area, 2015. Euro Surveill. 2016;21(48):30417. https://doi.org/10.2807/1560-7917. ES.2016.21.48.30417 PMID: 27934585 
19. Vourli G, Noori T, Pharris A, Porter K, Axelsson M, Begovac J, et al. Human immunodeficiency virus continuum of care in 11 European Union countries at the end of 2016 overall and by key population: have we made progress? Clin Infect Dis. 2020;71(11):2905-16. https://doi.org/10.1093/cid/ciaa696 PMID: 32960957

20. UNAIDS. AIDSinfo: Global data on HIV epidemiology and response. Geneva: UNAIDS. [Acccessed: 27 May 2021]. Available from: https://aidsinfo.unaids.org

21. European Centre for Disease Prevention and Control (ECDC). HIV prevalence in the EU/EEA: a systematic literature review. Forthcoming.

22. Moher D, Liberati A, Tetzlaff J, Altman DG, PRISMA Group. Preferred reporting items for systematic reviews and meta-analyses: the PRISMA statement. PLoS Med. 2009;6(7):e1000097. https://doi.org/10.1371/journal. pmed.1000097 PMID: 19621072

23. Klavs I, Bergant N, Kastelic Z, Lamut A, Kustec T. Disproportionate and increasing burden of HIV infection among men who have sex with men in Slovenia: surveillance data for 1999-2008. Euro Surveill. 2009;14(47):19419. https://doi. org/10.2807/ese.14.47.19419-en PMID: 19941802

24. Mirandola M, Gios L, Sherriff N, Marcus U, Toskin I, Rosinska $M$, et al. Quantifying unmet prevention needs among MSM in Europe through a multi-site bio-behavioural survey. Euro Surveill. 2018;23(49). https://doi.org/10.2807/1560-7917. ES.2018.23.49.1800097 PMID: 30621823

25. Kolarić B. Croatia: still a low-level HIV epidemic?-seroprevalence study. Coll Antropol. 2011;35(3):861-5. PMID: 22053568

26. Bozicevic I, Lepej SZ, Rode OD, Grgic I, Jankovic P, Dominkovic Z, et al. Prevalence of HIV and sexually transmitted infections and patterns of recent HIV testing among men who have sex with men in Zagreb, Croatia. Sex Transm Infect. 2012;88(7):539-44. https://doi.org/10.1136/ sextrans-2011-050374 PMID: 22628664

27. Pylli M, Middleton N, Charalambous A, Raftopoulos V. HIV prevalence, sexual and HIV testing behaviors among men who have sex with men in the Republic of Cyprus: 2011-2012 data from a cross-sectional study. BMC Infect Dis. 2014;14(1):432. https://doi.org/10.1186/1471-2334-14-432 PMID: 25100634

28. Mirandola M, Folch Toda C, Krampac I, Nita I, Stanekova D, Stehlikova D, et al. HIV bio-behavioural survey among men who have sex with men in Barcelona, Bratislava, Bucharest, Ljubljana, Prague and Verona, 2008-2009. Euro Surveill. 2009;14(48):19427. https://doi.org/10.2807/ese.14.48.19427en PMID: 20003897

29. Vanden Berghe W, Nostlinger C, Buvé A, Beelaert G, Fransen K, Laga M. A venue-based HIV prevalence and behavioural study among men who have sex with men in Antwerp and Ghent, Flanders, Belgium, October 2009 to March 2010. Euro Surveill. 2011;16(28):19914. https://doi.org/10.2807/ese.16.28.19914en PMID: 21794222

30. Amirkhanian YA, Kelly JA, Takacs J, Kuznetsova AV, DiFranceisco WJ, Mocsonaki L, et al. HIV/STD prevalence, risk behavior, and substance use patterns and predictors in Russian and Hungarian sociocentric social networks of men who have sex with men. AIDS Educ Prev. 2009;21(3):266-79. https://doi.org/10.1521/aeap.2009.21.3.266 PMID: 19519240

31. MCDaid LM, Hart GJ. Increased HIV testing and reduced undiagnosed infection among gay men in Scotland, 2005-8: support for the opt-out testing policy? Sex Transm Infect. 2011;87(3):221-4. https://doi.org/10.1136/sti.2010.044560 PMID: 21325443

32. Wallace LA, Li J, McDaid LM. HIV prevalence and undiagnosed infection among a community sample of gay and bisexual men in Scotland, 2005-2011: implications for HIV testing policy and prevention. PLoS One. 2014;9(3):e90805. https://doi. org/10.1371/journal.pone.0090805 PMID: 24621479

33. Aghaizu A, Wayal S, Nardone A, Parsons V, Copas A, Mercey D, et al. Sexual behaviours, HIV testing, and the proportion of men at risk of transmitting and acquiring HIV in London, UK, 2000-13: a serial cross-sectional study. Lancet HIV. 2016;3(9):e431-40. https://doi.org/10.1016/S23523018(16)30037-6 PMID: 27562744

34. Velter A, Barin F, Bouyssou A, Guinard J, Léon L, Le Vu S, et al. HIV prevalence and sexual risk behaviors associated with awareness of HIV status among men who have sex with men in Paris, France. AIDS Behav. 2013;17(4):1266-78. https://doi. org/10.1007/S10461-012-0303-1 PMID: 22968398

35. Sommen C, Saboni L, Sauvage C, Alexandre A, Lot F, Barin F, et al. Time location sampling in men who have sex with men in the HIV context: the importance of taking into account sampling weights and frequency of venue attendance. Epidemiol Infect. 2018;146(7):913-9. https://doi.org/10.1017/ S0950268818000675 PMID: 29606158
36. Etcheverry MF, de Lazzari E, Fuchs JD, Meroño M, Sierra E, Del Romero J, et al. Pilot study assessing HIV vaccine trial readiness among female sex workers, injection and noninjection drug users, and men who have sex with men in Spain. AIDS Behav. 2010;14(3):607-17. https://doi.org/10.1007/ S10461-008-9486-x PMID: 19037720

37. Folch C, Casabona J, Muñoz R, González V, Zaragoza K. Incremento en la prevalencia del VIH y en las conductas de riesgo asociadas en hombres que tienen sexo con hombres: 12 años de encuestas de vigilancia conductual en Cataluña. [Increase in the prevalence of HIV and in associated risk behaviors in men who have sex with men: 12 years of behavioral surveillance surveys in Catalonia (Spain)]. Gac Sanit. 2010;24(1):40-6. Spanish. https://doi.org/10.1016/j. gaceta.2009.06.010 PMID: 19962792

38. Achterbergh $R$, van der Helm IJ, van den Boom $W$, Heijman $T$, Stolte IG, van Rooijen MS, et al. Is rectal douching and sharing douching equipment associated with anorectal chlamydia and gonorrhoea? A cross-sectional study among men who have sex with men. Sex Transm Infect. 2017;93(6):431-7. https://doi. org/10.1136/sextrans-2016-052777 PMID: 28108702

39. Kolarić B, Stajduhar D, Gajnik D, Rukavina T, Wiessing L. Seroprevalence of blood-borne infections and population sizes estimates in a population of injecting drug users in Croatia. Cent Eur J Public Health. 2010;18(2):104-9. https://doi. org/10.21101/cejph.a3576 PMID: 20939261

40. Kolovrat A, Jurisić I, Marić Z, Cvitković A. Usporedba prevalencije biljega hepatitisa B, C i HIV-A medu intravenskim ovisnicima lijecenima ambulantno i u terapijskoj zajednici na podrucju Brodsko-posavske zupanije. [Prevalence of hepatitis $B$, hepatitis $C$ and HIV among injecting drug users treated outpatiently and in therapeutic community in Brod-Posavina County, Croatia]. Acta Med Croatica. 2010;64(4):287-96. Croatian. PMID: 21688612

41. Vilibić-Čavlek T, Kolarić B, Pavlić J, Kosanović-Ličina ML, Nemeth-Blažić T. Seroprevalence and Risk Factors for HIV, Hepatitis B, and Syphilis in Populations with Highrisk Behaviors in Croatia. Acta Dermatovenerol Croat. 2018;26(4):3147-320. PMID: 30665481

42. Handanagic S, Bozicevic I, Civljak M, Dominkovic Z, Sevic S, Barbaric J, et al. HIV and hepatitis ( prevalence, and related risk behaviours among people who inject drugs in three cities in Croatia: Findings from respondent-driven sampling surveys. Int J Drug Policy. 2016;32:57-63. https://doi.org/10.1016/j. drugpo.2016.04.007 PMID: 27160504

43. Wenz B, Nielsen S, Gassowski M, Santos-Hövener C, Cai W, Ross RS, et al. High variability of HIV and HCV seroprevalence and risk behaviours among people who inject drugs: results from a cross-sectional study using respondent-driven sampling in eight German cities (2011-14). BMC Public Health. 2016;16(1):927. https://doi.org/10.1186/s12889-016-3545-4 PMID: 27595567

44. Gyarmathy VA, Neaigus A, Li N, Ujhelyi E, Caplinskiene I, Caplinskas $S$, et al. Liquid drugs and high dead space syringes may keep HIV and HCV prevalence high - a comparison of Hungary and Lithuania. Eur Addict Res. 2010;16(4):220-8. https://doi.org/10.1159/000320287 PMID: 20798543

45. Origer A, Schmit JC. Prevalence of hepatitis B and C and HIV infections among problem drug users in Luxembourg: self-report versus serological evidence. J Epidemiol Community Health. 2012;66(1):64-8. https://doi.org/10.1136/ jech.2009.101378 PMID: 20889592

46. Blomé MA, Björkman P, Flamholc L, Jacobsson H, Molnegren V, Widell A. Minimal transmission of HIV despite persistently high transmission of hepatitis C virus in a Swedish needle exchange program. J Viral Hepat. 2011;18(12):831-9. https:// doi.org/10.1111/j.1365-2893.2010.01400.x PMID: 21114587

47. Marongiu A, Hope VD, Parry JV, Ncube F. Male IDUs who have sex with men in England, Wales and Northern Ireland: are they at greater risk of bloodborne virus infection and harm than those who only have sex with women? Sex Transm Infect. 2012;88(6):456-61. https://doi.org/10.1136/ sextrans-2011-050450 PMID: 22628667

48. Hickman M, Hope V, Coleman B, Parry J, Telfer M, Twigger J, et al. Assessing IDU prevalence and health consequences (HCV, overdose and drug-related mortality) in a primary care trust: implications for public health action. J Public Health (Oxf). 2009;31(3):374-82. https://doi.org/10.1093/pubmed/fdp067 PMID: 19596666

49. Hope VD, Harris R, McVeigh J, Cullen KJ, Smith J, Parry JV, et al. Risk of HIV and Hepatitis B and C over time among men who inject image and performance enhancing drugs in England and Wales: results from cross-sectional prevalence surveys, 19922013. J Acquir Immune Defic Syndr. 2016;71(3):331-7. https:// doi.org/10.1097/QAI.0000000000000835 PMID: 26361173

50. Hope VD, Harris RJ, De Angelis D, Croxford S, Marongiu A, Parry JV, et al. Two decades of successes and failures in controlling 
the transmission of HIV through injecting drug use in England and Wales, 1990 to 2011. Euro Surveill. 2014;19(14):20762. https://doi.org/10.2807/1560-7917.ES2014.19.14.20762 PMID: 24739984

51. Hope VD, Iversen J, Cullen KJ, Parry JV, Maher L, Nucbe F. Injection into the jugular vein among people who inject drugs in the United Kingdom: Prevalence, associated factors and harms. Int J Drug Policy. 2017;46:28-33. https://doi. org/10.1016/j.drugpo.2017.05.005 PMID: 28586700

52. McAuley A, Palmateer NE, Goldberg DJ, Trayner KMA Shepherd SJ, Gunson RN, et al. Re-emergence of HIV related to injecting drug use despite a comprehensive harm reduction environment: a cross-sectional analysis. Lancet HIV. 2019;6(5):e315-24. https://doi.org/10.1016/S23523018(19)30036-0 PMID: 30981674

53. Jauffret-Roustide M, Le Strat Y, Couturier E, Thierry D, Rondy M, Quaglia M, et al. A national cross-sectional study among drug-users in France: epidemiology of HCV and highlight on practical and statistical aspects of the design. BMC Infect Dis. 2009;9(1):113. https://doi.org/10.1186/1471-2334-9-113 PMID: 19607712

54. Weill-Barillet L, Pillonel J, Semaille C, Léon L, Le Strat Y, Pascal X, et al. Hepatitis C virus and HIV seroprevalences, sociodemographic characteristics, behaviors and access to syringes among drug users, a comparison of geographical areas in France, ANRS-Coquelicot 2011 survey. Rev Epidemiol Sante Publique. 2016;64(4):301-12. https://doi.org/10.1016/j. respe.2015.10.003 PMID: 26904917

55. Hatzakis A, Sypsa V, Paraskevis D, Nikolopoulos G, Tsiara C, Micha K, et al. Design and baseline findings of a large-scale rapid response to an HIV outbreak in people who inject drugs in Athens, Greece: the ARISTOTLE programme. Addiction. 2015;110(9):1453-67. https://doi.org/10.1111/add.12999 PMID: 26032121

56. Fotiou A, Kanavou E, Antaraki A, Richardson C, Terzidou M, Kokkevi A, Drug Related Infectious Diseases (DRID) Medical Doctors Group of OKANA. HCV/HIV coinfection among people who inject drugs and enter opioid substitution treatment in Greece: prevalence and correlates. Hepatol Med Policy. 2016;1(1):9. https://doi.org/10.1186/s41124-016-0017-5 PMID: 30288313

57. Camoni L, Regine V, Salfa MC, Nicoletti G, Canuzzi P, Magliocchetti $\mathrm{N}$, et al. Prevalence and correlates of infection with human immunodeficiency virus, hepatitis B virus, and hepatitis $C$ virus among drug users in Italy: a cross-sectional study. Scand J Infect Dis. 2009;41(6-7):520-3. https://doi. org/10.1080/00365540902946528 PMID: 19415569

58. Rosińska M, Sierosławski J, Wiessing L. High regional variability of HIV, HCV and injecting risks among people who inject drugs in Poland: comparing a cross-sectional biobehavioural study with case-based surveillance. BMC Infect Dis. 2015;15(1):83. https://doi.org/10.1186/s12879-015-0828-9 PMID: 25879904

59. Huntington S, Folch C, González V, Meroño M, Ncube F, Casabona J. Prevalencia del VIH, hepatitis $C$ y factores asociados en usuarios de drogas por vía parenteral seleccionados en Cataluña. [Prevalence of human immunodeficiency virus and hepatitis C virus, and associated factors among injecting drug users in Catalonia]. Enferm Infecc Microbiol Clin. 2010;28(4):236-8. Spanish. https://doi. org/10.1016/j.eimc.2009.06.004 PMID: 19695744

6o. Sanvisens A, Rivas I, Faure E, Muñoz T, Rubio M, Fuster D, et al. Características de los pacientes adictos a la heroína admitidos en un programa de tratamiento con metadona. [Characteristics of heroin dependent patients admitted to a methadone treatment program]. Med Clin (Barc). 2014;142(2):53-8. Spanish. https://doi.org/10.1016/j.medcli.2012.10.023 PMID: 23337454

61. Folch C, Casabona J, Brugal MT, Majó X, Esteve A, Meroño M, et al. Sexually transmitted infections and sexual practices among injecting drug users in harm reduction centers in Catalonia. Eur Addict Res. 2011;17(5):271-8. https://doi. org/10.1159/000329931 PMID: 21791924

62. Folch C, Casabona J, Espelt A, Majó X, Meroño M, Gonzalez $V$, et al. Gender differences in HIV risk behaviours among intravenous drug users in Catalonia, Spain. Gac Sanit. 2013;27(4):338-43. https://doi.org/10.1016/j. gaceta.2013.02.006 PMID: 23578527

63. Folch C, Casabona J, Espelt A, Majó X, Meroño M, Gonzalez V, et al. High prevalence and incidence of HIV and HCV among new injecting drug users with a large proportion of migrants-is prevention failing? Subst Use Misuse. 2016;51(2):250-60. https://doi.org/10.3109/10826084.2015.1092991 PMID: 26820260

64. Uusküla A, Des Jarlais DC, Kals M, Rüütel K, Abel-Ollo K, Talu $A$, et al. Expanded syringe exchange programs and reduced HIV infection among new injection drug users in Tallinn,
Estonia. BMC Public Health. 2011;11(1):517. https://doi. org/10.1186/1471-2458-11-517 PMID: 21718469

65. Uusküla A, Raag M, Vorobjov S, Rüütel K, Lyubimova A, Levina OS, et al. Non-fatal overdoses and related risk factors among people who inject drugs in St. Petersburg, Russia and KohtlaJärve, Estonia. BMC Public Health. 2015;15(1):1255. https://doi. org/10.1186/s12889-015-2604-6 PMID: 26684815

66. Derks L, Gassowski M, Nielsen S, An der Heiden M, Bannert N, Bock CT, et al. Risk behaviours and viral infections among drug injecting migrants from the former Soviet Union in Germany: Results from the DRUCK-study. Int I Drug Policy. 2018;59:54-62. https://doi.org/10.1016/j.drugpo.2018.06.011 PMID: 30005420

67. Hernández-Fernández T, Arroyo-Cobo JM. Resultados de la experiencia española: una aproximación global al VIH y al VHC en prisiones. [Results of the Spanish experience: a comprehensive approach to HIV and HCV in prisons]. Rev Esp Sanid Penit. 2010;12(3):86-90. Spanish. PMID: 23128565

68. Burek V, Horvat J, Butorac K, Mikulić R. Viral hepatitis $B, C$ and HIV infection in Croatian prisons. Epidemiol Infect. 2010;138(11):1610-20. https://doi.org/10.1017/ So950268810000476 PMID: 20202285

69. Viitanen P, Vartiainen H, Aarnio J, von Gruenewaldt V, Hakamäki S, Lintonen T, et al. Hepatitis A, B, C and HIV infections among Finnish female prisoners--young females a risk group. J Infect. 2011;62(1):59-66. https://doi. org/10.1016/j.jinf.2010.10.011 PMID: 21087630

70. Schulte B, Stöver H, Thane K, Schreiter C, Gansefort D, Reimer J. Substitution treatment and HCV/HIV-infection in a sample of 31 German prisons for sentenced inmates. Int J Prison Health. 2009;5(1):39-44. https://doi.org/10.1080/17449200802692144 PMID: 25758928

71. Tresó B, Barcsay E, Tarján A, Horváth G, Dencs A, Hettmann A, et al. Prevalence and correlates of HCV, HVB, and HIV infection among prison inmates and staff, Hungary. J Urban Health. 2012;89(1):108-16. https://doi.org/10.1007/s11524-011-9626-x PMID: 22143408

72. Vanya M, Szili K, Magori K, Krisztina V. Skin diseases and sexually transmitted infection in a Hungarian prison. Rev Med Microbiol. 2017;28(3):95-6. https://doi.org/10.1097/ MRM.0000000000000087

73. Semaille C, Le Strat Y, Chiron E, Chemlal K, Valantin MA, Serre $P$, et al. Prevalence of human immunodeficiency virus and hepatitis $C$ virus among French prison inmates in 2010: a challenge for public health policy. Euro Surveill. 2013;18(28):20524. https://doi.org/10.2807/1560-7917. ES2013.18.28.20524 PMID: 23870097

74. Sagnelli E, Starnini G, Sagnelli C, Monarca R, Zumbo G, Pontali $E$, et al. Blood born viral infections, sexually transmitted diseases and latent tuberculosis in italian prisons: a preliminary report of a large multicenter study. Eur Rev Med Pharmacol Sci. 2012;16(15):2142-6. PMID: 23280032

75. Sinisgalli E, Silvestri C, Bravi S, Ceccherini V, Tanini T, Bonaccorsi G, et al. Infectious diseases in the Tuscan detention setting: data from the Health Agency of Tuscany. Public Health. 2016;141:264-7. https://doi.org/10.1016/j.puhe.2016.02.019 PMID: 27126919

76. Monarca R, Madeddu G, Ranieri R, Carbonara S, Leo G, Sardo $M$, et al. HIV treatment and care among Italian inmates: a one month point survey. BMC Infect Dis. 2015;15(1):562. https:// doi.org/10.1186/s12879-015-1301-5 PMID: 26653247

77. Marques NM, Margalho R, Melo MJ, Cunha JG, Meliço-Silvestre AA. Seroepidemiological survey of transmissible infectious diseases in a portuguese prison establishment. Braz J Infect Dis. 2011;15(3):272-5. https://doi.org/10.1590/S1413. 86702011000300016 PMID: 21670930

78. Ferrer-Castro V, Crespo-Leiro MR, García-Marcos LS, PérezRivas M, Alonso-Conde A, García-Fernández I, et al. Evaluación del programa de intercambio de jeringuillas en el centro penitenciario de Pereiro de Aguiar (Ourense): diez años de experiencia. [Evaluation of needle exchange program at Pereiro de Aguiar prison (Ourense, Spain): ten years of experience]. Rev Esp Sanid Penit. 2012;14(1):3-11. Spanish. https://doi. org/10.4321/S1575-06202012000100002 PMID: 22437903

79. Marco A, Saiz de la Hoya P, García-Guerrero J, Grupo PREVALHEP. Estudio multicéntrico de Prevalencia de Infección por el VIH y factores asociados en las prisiones de España. Multi-centre study of the prevalence of infection from HIV and associated factors in Spanish prisons]. Rev Esp Sanid Penit. 2012;14(1):19-27. Spanish. https://doi.org/10.4321/S157506202012000100004 PMID: 22437905

80. Kivimets K, Uuskula A. HIV testing and counselling in Estonian prisons, 2012 to 2013: aims, processes and impacts. Euro Surveill. 2014;19(47):20970. https://doi.org/10.2807/15607917.ES2014.19.47.20970 PMID: 25443037

81. van Veen MG, Götz HM, van Leeuwen PA, Prins $M$, van de Laar MJ. HIV and sexual risk behavior among commercial sex 
workers in the Netherlands. Arch Sex Behav. 2010;39(3):71423. https://doi.org/10.1007/s10508-008-9396-z PMID: 18815876

82. Fournet N, Koedijk FD, van Leeuwen AP, van Rooijen MS, van der Sande MA, van Veen MG. Young male sex workers are at high risk for sexually transmitted infections, a cross-sectional study from Dutch STI clinics, the Netherlands, 2006-2012. BMC Infect Dis. 2016;16(1):63. https://doi.org/10.1186/s12879-0161388-3 PMID: 26847196

83. Verscheijden MMA, Woestenberg PJ, Götz HM, van Veen MG, Koedijk FDH, van Benthem BHB. Sexually transmitted infections among female sex workers tested at STI clinics in the Netherlands, 2006-2013. Emerg Themes Epidemiol. 2015;12(1):12. https://doi.org/10.1186/s12982-015-0034-7 PMID: 26322117

84. Zermiani M, Mengoli C, Rimondo C, Galvan U, Cruciani M, Serpelloni G. Prevalence of sexually transmitted diseases and hepatitis $C$ in a survey of female sex workers in the north-East of Italy. Open AIDS J. 2012;6(1):60-4. https://doi.org/10.2174/1 874613601206010060 PMID: 22833775

85. Folch C, Casabona J, Sanclemente C, Esteve A, González V, Grupo HIVITS-TS. Tendencias de la prevalencia del VIH y de las conductas de riesgo asociadas en mujeres trabajadoras del sexo en Cataluña. [Trends in HIV prevalence and associated risk behaviors in female sex workers in Catalonia (Spain)]. Gac Sanit. 2014;28(3):196-202. Spanish. https://doi.org/10.1016/j. gaceta.2013.11.004 PMID: 24393261

86. Platt L, Grenfell P, Bonell C, Creighton S, Wellings K, Parry J, et al. Risk of sexually transmitted infections and violence among indoor-working female sex workers in London: the effect of migration from Eastern Europe. Sex Transm Infect. 2011;87(5):377-84. https://doi.org/10.1136/sti.2011.049544 PMID: 21572111

87. Dias S, Gama A, Fuertes R, Mendão L, Barros H. Risktaking behaviours and HIV infection among sex workers in Portugal: results from a cross-sectional survey. Sex Transm Infect. 2015;91(5):346-52. https://doi.org/10.1136/ sextrans-2014-051697 PMID: 25512671

88. Dias S, Gama A, Pingarilho M, Simões D, Mendão L. Health services use and HIV prevalence among migrant and national female sex workers in Portugal: are we providing the services needed? AIDS Behav. 2017;21(8):2316-21. https://doi. org/10.1007/s10461-016-1511-x PMID: 27475942

89. Luzzati R, Zatta M, Pavan N, Serafin M, Maurel C, Trombetta C, et al. Prevalence of human immunodeficiency virus, hepatitis $B$ virus, and hepatitis $C$ virus infections among transgender persons referred to an Italian Center for total sex reassignment surgery. Sex Transm Dis. 2016;43(7):407-11. https://doi. org/10.1097/OLQ.0000000000000452 PMID: 27322038

90. Reyes-Urueña JM, Campbell CNJ, Vives N, Esteve A, Ambrosioni J, Tural C, et al. Estimating the HIV undiagnosed population in Catalonia, Spain: descriptive and comparative data analysis to identify differences in MSM stratified by migrant and Spanishborn population. BMJ Open. 2018;8(2):e018533. https://doi. org/10.1136/bmjopen-2017-018533 PMID: 29490955

91. Marty L, Van Beckhoven D, Ost C, Deblonde J, Costagliola D, Sasse A, et al. Estimates of the HIV undiagnosed population in Belgium reveals higher prevalence for MSM with foreign nationality and for geographic areas hosting big cities. J Int AIDS Soc. 2019;22(8):e25371. https://doi.org/10.1002/ jia2.25371 PMID: 31424626

92. Marty L, Cazein F, Panjo H, Pillonel J, Costagliola D, Supervie V, HERMETIC Study Group. Revealing geographical and population heterogeneity in HIV incidence, undiagnosed HIV prevalence and time to diagnosis to improve prevention and care: estimates for France. J Int AIDS Soc. 2018;21(3):e25100. https://doi.org/10.1002/jia2.25100 PMID: 29603879

93. Niculescu I, Paraschiv S, Paraskevis D, Abagiu A, Batan I, Banica L, et al. Recent HIV-1 outbreak among intravenous drug users in Romania: Evidence for cocirculation of CRF14 BG and Subtype F1 Strains. AIDS Res Hum Retroviruses. 2015;31(5):488-95. https://doi.org/10.1089/aid.2014.0189 PMID: 25369079

94. Hedrich D, Kalamara E, Sfetcu O, Pharris A, Noor A, Wiessing $L$, et al. Human immunodeficiency virus among people who inject drugs: is risk increasing in Europe? Euro Surveill. 2013;18(48):20648. https://doi.org/10.2807/1560-7917. ES2013.18.48.20648 PMID: 24308980

95. Des Jarlais DC, Feelemyer JP, Modi SN, Arasteh K, Hagan H. Are females who inject drugs at higher risk for HIV infection than males who inject drugs: an international systematic review of high seroprevalence areas. Drug Alcohol Depend. 2012;124(12):95-107. https://doi.org/10.1016/j.drugalcdep.2011.12.020 PMID: 22257753

96. European Monitoring Centre for Drugs and Drug Addiction (EMCDDA). Prisons and drugs in Europe: the problem and responses. Lisbon: EMCDDA; 2012. Available from: https:// www.emcdda.europa.eu/publications/selected-issues/ prison_en

97. Alvarez-Del Arco D, Fakoya I, Thomadakis C, Pantazis N, Touloumi G, Gennotte AF, et al. High levels of postmigration HIV acquisition within nine European countries. AIDS. 2017;31(14):1979-88. https://doi.org/10.1097/ QAD.0000000000001571 PMID: 28857779

98. Hankins CA, de Zalduondo BO. Combination prevention: a deeper understanding of effective HIV prevention. AIDS. 2010;24(Suppl 4):S70-80. https://doi.org/10.1097/01. aids.0000390709.04255.fd PMID: 21042055

99. Joint United Nations Programme on HIV/AIDS (UNAIDS). Combination HIV prevention: Tailoring and coordinating biomedical, behavioural and structural strategies to reduce new HIV infections. A UNAIDS Discussion Paper. Geneva: UNAIDS; 2010. Available from: https://www.unaids.org/en/ resources/documents/2010/20101006_JC2007_Combination Prevention_paper

100. Neumann MS, Finlayson TJ, Pitts NL, Keatley J. Comprehensive HIV prevention for transgender persons. Am J Public Health. 2017;107(2):207-12. https://doi.org/10.2105/ AJPH.2016.303509 PMID: 27997228

\section{License, supplementary material and copyright}

This is an open-access article distributed under the terms of the Creative Commons Attribution (CC BY 4.0) Licence. You may share and adapt the material, but must give appropriate credit to the source, provide a link to the licence and indicate if changes were made.

Any supplementary material referenced in the article can be found in the online version.

This article is copyright of the authors or their affiliated institutions, 2021. 